

Horyzonty Polityki 2020, Vol. 11, No 35

\section{Marcin WichmanowsKi}

\author{
http://orcid.org/0000-0001-5748-7946 \\ Uniwersytet Marii Curie-Skłodowskiej w Lublinie \\ Wydział Politologii i Dziennikarstwa \\ Instytut Nauk o Polityce i Administracji \\ marcin.wichmanowski@poczta.umcs.lublin.pl
}

DOI: $10.35765 / H P .1879$

\title{
Inspiracje naturą chłopską myśli politycznej ruchu ludowego w końcowym okresie zaborów i w II Rzeczypospolitej
}

\section{Streszczenie}

CEL NAUKOWY: Za naczelny cel przyjęto ustalenie wzajemnych związków zachodzących pomiędzy myślą polityczną ruchu ludowego w Polsce w końcowym okresie zaborów i dwudziestoleciu międzywojennym a naturą chłopską.

PROBLEM I METODY BADAWCZE: Pojawiło się pytanie, czy każda z podstawowych kategorii myśli politycznej ruchu ludowego była inspirowana naturą chłopską oraz czy następowało sprzężenie zwrotne - myśl wpływała na naturę. Niezbędne dla ukazania problemu było zastosowanie metod i technik badawczych swoistych dla badań nad myślą polityczną przede wszystkim analizy świadectw i śladów myśli politycznej partii ludowych, a także analizy porównawczej. Takie podejście badawcze pozwoliło na uchwycenie swoistości eksplorowanego problemu.

PROCES WYWODU: W pierwszej kolejności przedstawiono definicje podstawowych pojęć (myśl polityczna, ruch ludowy, natura chłopska). Następnie zwrócono uwagę na uwarunkowania natury chłopskiej oraz rolę, jaką odgrywała w kształtowaniu ideologii ruchu ludowego w Polsce. Ukazano wpływ warunków społeczno-politycznych na chłopską naturę, a jej na rozwój myśli politycznej partii ludowych.

WYNIKI ANALIZY NAUKOWEJ: Chłopi stanowili dla polityków ruchu ludowego fundament społeczeństwa i narodu, byli inspiracją dla koncepcji i działań politycznych. W artykule starano się udowodnić, na ile warunki życia chłopów determinowały ich naturę, a natura chłopska myśl ludowców. 
WNIOSKI, INNOWACJE, REKOMENDACJE: Wnioski płynące z rozważań zawartych w artykule adresowane są zarówno do polityków, politologów, jak i socjologów wsi. Ukazano sposób, w jaki ideolodzy ruchu ludowego udowodnili, że wszelkie działanie polityczne ma uzasadnienie wówczas, gdy jego wyniki i efekty służą człowiekowi. Stąd pojawił się postulat przebudowy psychiki chłopa (uszlachetniania go).

\title{
SŁOWA KLUCZOWE:
}

ruch ludowy, natura chłopska, myśl polityczna

\author{
Abstract \\ THE PEASANT NATURE INSPIRATIONS OF THE \\ POLITICAL THOUGHT OF THE POLISH PEOPLE'S \\ MOVEMENT AT THE END OF THE PARTITIONS \\ PERIOD AND IN THE SECOND POLISH REPUBLIC
}

RESEARCH OBJECTIVE: We adopted establishment of mutual relations between the political thought of the people's movement in Poland at the end of the partitions and the interwar period, and peasant nature as the main objective of our work.

THE RESEARCH PROBLEM AND METHODS: The question arose, whether each of the basic categories of political thought of the people's movement was inspired by peasant nature, and whether there was any feedback - with thought affecting the said nature. The highlighting of this issue necessitated using research methods and techniques specific to the exploration of research on political thought; first of all, analysis of testimonies and traces of political thought of popular parties, as well as comparative analysis. This research approach enabled us to capture the specificity of the investigated issue.

THE PROCESS OF ARGUMENTATION: We set off presenting definitions of the basic concepts (political thought, people's movement, peasant nature) first. Then, attention was paid to the conditions of the peasant nature and the role it played in shaping the ideology of the people's movement in Poland. The influence of socio-political conditions on peasant nature were demonstrated, and their influence on the development of political thought of popular parties.

RESEARCH RESULTS: Peasants constituted the cornerstone of society and the nation for the politicians of the people's movement, they were the inspiration for their political concepts and actions. The article attempts to prove to what extent the living conditions of the peasants determined their nature and the peasant nature the thought of the people's movement. 
CONCLUSIONS, INNOVATIONS, AND RECOMMENDATIONS: We address the conclusions drawn from considerations contained in the article to both politicians, political scientists and rural sociologists. They demonstrate the way ideologists of the people's movement have proved that all political action is justified, as long as its results and effects serve man. Hence the demand for rebuilding the peasant's psyche (refining it).

\section{KeYwORDS:}

people's movement, peasant nature, political thought

\section{WSTĘP}

Myśl polityczna, ruch ludowy, chłopi - to pojęcia, które nie zużyły się jako politologiczne kategorie badawcze. Są nośnikiem ważnych treści i konotacji. W opracowaniu przeprowadzono analizę wybranych zagadnień związanych z tymi terminami. Istotnym dla tematu było również zdefiniowanie pojęcia „natury chłopskiej”. Według Słownika myśli politycznej Rogera Scrutona:

Każda doktryna polityczna musi być ufundowana na teorii natury ludzkiej. Spory o doktryny polityczne zazwyczaj odzwierciedlają różnice poglądów na ludzką naturę (...) natura ludzka jest całkowicie nieprzenikniona, objawia się tylko w wydarzeniach ludzkich dziejów. Ponadto niełatwo ją opisać za pomocą pojęć, które byłyby na tyle niebanalne, aby dało się na nich zbudować wyrazistą doktrynę bądź też na tyle niedoktrynalne, aby miały uniwersalną wartość (Scruton, 2002, s. 231-232).

Podążając tym tokiem rozumowania, „natura chłopska” obejmuje szerokie znaczenie. Związana była m.in. z charakterem, psychiką ludzi wyrosłych na wsi, zajmujących się rolnictwem, będących często najniższą warstwą społeczną. $W$ artykule przeanalizowane zostały podstawowe inspiracje związane z naturą chłopów polskich, które miały wpływ na myśl polityczną partii ludowych w końcowym okresie zaborów i Polsce okresu międzywojennego.

Istotnym elementem rzeczywistości politycznej jest myśl polityczna, będąca przedmiotem badań politologicznych. Należy w niej dostrzegać nie tylko składnik świadomości, ale również intelektualną podstawę procesów decyzyjnych. Refleksja nad myślą polityczną jest 
niezbędna, aby zrealizować określoną przez Andrzeja Garlickiego dyrektywę:

Historyk, jeśli chce zrozumieć i ocenić postępowanie ludzi przeszłości, nie może ograniczać się jedynie do odtwarzania ich działań, ale musi dążyć do zbadania motywów tych działań. A to właśnie oznacza również rozpatrywanie możliwości niespełnionych (Garlicki, 1981, s. 6).

To przesłanie metodologiczne, na co zwrócił uwagę Waldemar Paruch (2005, s. 9), obowiązuje również politologów, przynajmniej z tej ogólnej racji, że polityka jako konstytutywny składnik rzeczywistości politycznej ma związane ze sobą wymiary praktyki i refleksji. W obu z nich występuje myślenie polityczne, którego efektem jest myśl polityczna. Prowadzone badania nad kształtem, charakterem i dziejami myśli politycznej przynoszą liczne definicje, które z reguły wskazują podmiot dociekań naukowych, wyznaczają dziedzinę zainteresowań oraz sposoby artykulacji poglądów politycznych wybranych ruchów politycznych, partii i ich ideologów. Można więc zgodzić się z badaczami, którzy rozumienie pojęcia "myśl polityczna” traktują szeroko. W ten też sposób należy traktować termin „myśl polityczna” użyty w tytule artykułu, który został sformułowany „"w istocie wszelkiej formy refleksji nad rzeczywistością polityczną" (Jachymek, Paruch, 2001, s. 10-12; Jachymek, 1983, s. 9; Paruch, 1997, s. 12-14; 1999, s. $27-$ 40; 2015, s. 157-174; 2005, s. 9-11; 2004, s. 11-12; 2006, s. 207-214; 2009, s. 37-46; Wójcik, 1992, s. 7; Maj, Wójcik, 2008, s. 7; Olszewski, 2015, s. 153-173; Zieliński, 1975, s. 7-26; Wapiński, 1987, s. 52; 1990, s. 169178; Łuczak, 1982, s. 6; Zakrzewski, 1988, s. 121-134; Czarnota, 1988, s. 271; Skarzyński, 1990, s. 9-27; 1992, s. 107-119; Król, 1998, s. 5-6; Jajecznik, 2006, s. 255-259).

Natomiast ruch ludowy, zgodnie z definicją czołowego badacza zajmującego się problematyką Jana Jachymka (1993; 2001, s. 221, 223), to całokształt samodzielnej pracy różnych organizacji: politycznych, gospodarczych, kulturalno-oświatowych i innych, służących Polsce oraz godnemu w niej miejscu chłopów. Prymarnymi komponentami ruchu były przede wszystkim stronnictwa ludowe, ale również, w dalszej kolejności, organizacje młodzieży wiejskiej, kółka rolnicze, straże pożarne, różnego rodzaju organizacje spółdzielcze i rolnicze działające na wsi, a także uniwersytety ludowe, teatry, chóry oraz wiele innych (Wichmanowski, 2019, s. 314-315; 
Inspiracje naturą chłopską myśli politycznej ruchu ludowego

Gmitruk, Indraszczyk, 2016; Cimek, 2007). Ruch ludowy kształtował się na ziemiach polskich pod zaborami na przełomie XIX i XX wieku w różnych warunkach. Największe znaczenie polityczne ludowcy osiągnęli w niepodległej Polsce. Do liczących się partii ludowych w II Rzeczypospolitej należały: Polskie Stronnictwo Ludowe „Piast”, Polskie Stronnictwo Ludowe „Wyzwolenie”, Stronnictwo Chłopskie i powstałe w wyniku ich połączenia w 1931 roku - Stronnictwo Ludowe, które było najliczniejszą polską partią w latach trzydziestych XX wieku (Wichmanowski, 2019, s. 314).

Celem artykułu było ustalenie wzajemnych związków zachodzących pomiędzy myślą polityczną stronnictw ludowych a naturą chłopską. W następstwie pojawiło się pytanie, czy każda z podstawowych kategorii myśli politycznej była inspirowana naturą chłopską oraz czy następowało sprzężenie zwrotne - myśl wpływała na naturę. Niezbędne dla ukazania problemu było zastosowanie metod i technik badawczych swoistych dla badań nad myślą polityczną, przede wszystkim analizy świadectw i śladów myśli politycznej partii ludowych, a także analizy porównawczej, jak również metod historycznych, instytucjonalno-prawnej oraz ujęcia ilościowego. Takie podejście badawcze pozwoliło na uchwycenie swoistości eksplorowanego problemu.

\section{NATURA CHŁOPSKA}

Chłop reprezentował wyraźnie nakreślony typ psychiczności, który można nazwać naturą lub charakterem chłopskim. Ta swoista i wyraziście wyodrębniająca się na tle innych typów psychiki zbiorowej np. mieszczańskiej czy szlacheckiej natura czy charakter, ukształtowały

1 Od początku zorganizowanej działalności politycznej polski ruch ludowy nie był jednolity pod względem polityczno-organizacyjnym. Ziemie polskie, wtłoczone w trzy różne organizmy państwowe, wykazywały także specyfikę w działalności stronnictw ludowych. Ludowcy pod zaborem rosyjskim działali $w$ warunkach ostrych represji politycznych. Stronnictwa ludowe pod zaborem pruskim skupiały się na obronie polskiego stanu posiadania. Natomiast ruch ludowy w Galicji rodził się, korzystając ze znacznych swobód politycznych i narodowych, gwarantowanych konstytucją z 21 grudnia 1867 roku (Wichmanowski, 2017, s. 7). 
się w długich i osobliwych dziejach, w nader trudnym i swoistym sposobie bytowania tej warstwy społecznej, w jej wiekowych zmaganiach z przyrodą ziemią i różnymi, na ogół nieprzychylnymi, czynnikami społecznymi i politycznymi. Uformowała się $\mathrm{w}$ toku wykonywania ciężkiej, mozolnej pracy, w warunkach tradycyjnej, przez całe stulecia zamkniętej kultury i obyczajowości chłopskiej. Natura chłopska przejawiała się głównie w sferze postaw, aktywności, w kulturze ludowej oraz w świecie wartości wykreowanych przez społeczność wiejską.

Do istotnych pozytywnych cech natury chłopskiej znani działacze i politycy ruchu ludowego zaliczyli: pracowitość, poczucie obowiąz$\mathrm{ku}$, swoisty stosunek do ziemi, poczucie godności i honoru, wytrwałość, upór, umiar, realizm, religijność, gotowość wsparcia sąsiada w potrzebie i inne. Z poczuciem godności i honoru chłopa pozostawały jednak w pewnej sprzeczności inne cechy postawy i mentalność, o których pisali obserwatorzy życia chłopskiego, m.in. poczucie niższości wobec niektórych grup społecznych, „,cnota pokory”, , "niedostatek inicjatywy", pijaństwo, porywczość (Szmyd, 1996, s. 14-15).

Cechy natury chłopskiej opisał znany polityk ruchu ludowego Wincenty Witos:

Chłop, uważał się za niższe i mniej wartościowe stworzenie od innych, nie tylko, że w to sam święcie wierzył, ale i drugich $w$ tym umacniał, obniżając rozmyślnie swoją wartość w ich oczach (...).

Zupełnie inaczej odnosił się chłop do swoich sąsiadów:

Wobec nich nie tylko nie czuł żadnej niższości, ale starał się na każdym kroku okazywać większą wartość i znaczenie, jeśli tylko znalazł do tego choćby najmniejszą podstawę (Witos, 1998, s. 64, 67).

Dwoistość natury chłopskiej występowała przez dziesiątki lat i wiązała ze sobą wiele pokoleń. Ta typologia razi jednak swoistym schematyzmem najczęściej formułowanej charakterystyki osobowości tradycyjnej przypisywanej chłopom. Ogólnikowe sądy podważyli autorzy licznych pamiętników chłopów i monografii ${ }^{2}$ (Słomka, 1983).

2 W Archiwum Zakładu Historii Ruchu Ludowego w Warszawie, w zespole wspomnień i życiorysów, znajdują się m.in. „Wspomnienia” Aleksandra Bogusławskiego, których fragmenty dotyczą charakterystyki chłopów. Także 
Badając dzieje narodu polskiego bez uwzględnienia tak wielkiej jego części, jaką stanowili chłopi, skazuje się każdą refleksję na niekompletność i stronniczość, płynącą z niedocenienia procesów długiego trwania. „Historia chłopów w społeczeństwie polskim (...) jest historią tego społeczeństwa pisaną z perspektywy jego największej zbiorowości" (Bukraba-Rylska, 2008, s. 106-107). Historia chłopów polskich miała początek $\mathrm{w}$ okresie wyodrębniania się ludności, która zajmowała się rolnictwem, jako osobnej kategorii społecznej. Był to okres pierwszych Piastów i kształtowania się grup związanych z instytucją państwa (grupa wojowników, urzędników, kupców, rzemieślników i rolników). Każda z grup społecznych nabywała prawa i obowiązki wobec struktur państwowych i społeczeństwa, i zajmowała określoną pozycję w hierarchii społecznej. Pierwsze podziały nie degradowały ekonomicznie i społecznie żadnej z grup. Nie miały charakteru wartościującego, lecz wskazywały na rodzaj wykonywanej pracy. Ludność rolniczą zwano kmieciami. Określenie to pochodziło od łacińskiego słowa comes i oznaczało wolnego, niezależnego gospodarza (Samulak, 1997, s. 11-12).

Pod koniec XV wieku stan kmiecy przegrał z systemem folwarczno-pańszczyźnianym. Nową pozycję ludności kmiecej określało pojęcie chłop, które w okresie feudalizmu oznaczało całą nieszlachecką ludność wiejska, pozostającą w stosunku poddańczym do feudałów. Konsekwencją przypisania chłopów do ziemi było wytworzenie się społeczności statycznej, przeświadczonej o niezmienności własnych losów i otaczającego świata (Samulak, 1997, s. 11-12; Banach, 1997, s. 84). Okres pańszczyzny był niejednokrotnie negatywnie oceniany przez współczesnych, m.in. Jan z Ludziska porównywał położenie chłopów do niewoli „synów Izraela w Egipcie”. Ze stanowiska równości wobec Boga i miłości bliźniego krytykowali położenie chłopów Andrzej Frycz Modrzewski i Piotr Skarga, którzy w ucisku chłopów i poddaństwie dopatrywali się przyczyn słabości państwa. Odrzucali przypisywane naturze chłopskiej jako wrodzone ujemne cechy: pijaństwo, ciemnotę i skłonność do buntu, charakteryzujące chłopów przez stulecia. Twierdzili, że nie są to przywary trwałe, z którymi

w publikacji Józefa Chałasińskiego (1984) pt. Młode pokolenie chłopów: procesy i zagadnienia kształtowania się warstwy chłopskiej w Polsce, t. 1-4, można znaleźć obszerne opisy kształtowania się na ziemiach polskich warstwy chłopskiej. 
chłop się urodził, lecz nabyte, spowodowane systemem folwarczno-pańszczyźnianym (Samulak, 1997, s. 12-13).

Momentem przełomowym, od którego zaczął się zasadniczy zwrot w dziejach wsi polskiej, było uwłaszczenie i zniesienie pańszczyzny. W epoce popańszczyźnianej chłopi musieli dokonać przede wszystkim gruntownej zmiany w sposobie myślenia, wyjść z izolacji przestrzennej i społecznej, by w przyszłości stać się pełnoprawnymi członkami narodu polskiego (Banach, 1997, s. 84). Rezultaty uwłaszczenia w poszczególnych zaborach były w znacznym stopniu zdeterminowane przez warunki gospodarcze i polityczne. Proces uwłaszczenia na ziemiach polskich rozpoczął się w pierwszej połowie XIX wieku. W zaborze pruskim w 1807 roku zniesiono poddaństwo osobiste chłopów, a następnie przez ok. 50 lat trwało likwidowanie pańszczyzny i przekazywanie ziemi chłopom. W zaborze rosyjskim na terenie Księstwa Warszawskiego prawodawstwo Napoleona zlikwidowało poddaństwo także w 1807 roku, a zniesienie pańszczyzny i uwłaszczenie dokonało się w guberniach zachodnich w latach 1861 i 1863, w Królestwie Polskim mocą jednorazowego aktu w 1864 roku. W zaborze austriackim zniesiono poddaństwo i zarazem przeprowadzono uwłaszczenie w roku 1848 (Bukraba-Rylska, 2008, s. 123).

Za niewątpliwą konsekwencję pańszczyzny uznano uformowanie pewnego typu osobowości, który utrzymywał się mimo zmiany warunków społecznych. Koncentrowano się głównie na aspektach negatywnych, wpisując $\mathrm{w}$ ten wzór różne treści. Jednym z pierwszych, który zwrócił uwagę na problem, był znany działacz, publicysta i polityk ludowy Jakub Bojko (1904, s. 1-107). W książce Dwie dusze scharakteryzował najgroźniejszą jego zdaniem spuściznę czasów pańszczyźnianych, która wpłynęła na kształt chłopskiej natury, a dotyczyła kilku pokoleń chłopów. Charakteryzowały ją obecne w psychice chłopskiej pokłady kompleksów, obaw i pokory wobec władzy, co uniemożliwiało skuteczne zabieganie o należne prawa, a nawet skłaniało do zdrady interesów grupowych, przy jednoczesnej skłonności do wywyższania się i okazywania pogardy innym (Bukraba-Rylska, 2008, s. 126). Kolejni autorzy opisujący chłopską naturę akcentowali również "chłopską duszę pańszczyźnianą" i podkreślali nie tylko trwałość tego wzorca osobowego, ale również uporczywą powtarzalność w różnych warunkach. Wzorzec ten mimo zachodzących zmian zachował podstawowe cechy poddaństwa. Przykładem mogła być 
kondycja „,beznadziejnego proletariatu”, która wywodziła się wprost z tradycji pańszczyźnianej, następnie odrodziła się w zbiorowości „wolnych najmitów" - najemnej siły roboczej w folwarkach i dużych chłopskich gospodarstwach (Bukraba-Rylska, 2008, s. 125-126).

Kształtowanie się narodu polskiego trwało stulecia. Umasowienie tego procesu nastąpiło w XIX wieku. Postępom asymilacji państwowej w łonie aktywnej części społeczeństwa sekundował powszechny indyferentyzm narodowy chłopów. W tej warstwie społecznej świadomość narodowa rozwinęła się najpóźniej. Czynnikiem hamującym rozwój świadomości narodowej chłopów był wszechobecny analfabetyzm i mit monarchy dobroczyńcy, który zniósł pańszczyznę i obdarzył ich prawami i wolnością. Dla chłopów Polakami byli panowie, chłop był tutejszy, miejscowy. Rozwój świadomości narodowej, a także aktywności obywatelskiej chłopów zależał od poziomu ich oświaty, zamożności i cywilizacji. Najwcześniej na poglądy chłopów miały wpływ założenia ideowe ruchu narodowego, który na ziemiach polskich od końca XIX wieku prowadził szeroką akcję oświatową. Później, po ukształtowaniu się stronnictw ludowych, to one przejęły inicjatywę (Wichmanowski, 2010b, s. 161-162). Nieodłączny element myśli politycznej partii ludowych stanowiły koncepcje oświatowe, z których wynikały kolejne. Oświatę traktowano jako najważniejszy warunek i czynnik ",przewrotu” w psychice i umysłowości chłopów. U progu niepodległości ugrupowania ludowe posiadały własny program oświatowy wywodzący się z założeń wypracowanych jeszcze w okresie zaborów i dążyły do jego implementacji w odrodzonej Polsce za pośrednictwem demokratycznej drogi parlamentarnej. Ponieważ największą część społeczeństwa stanowili chłopi, interes państwa wymagał, aby jak najszybciej mogli osiągnąć taki poziom kulturalny, społeczny i ekonomiczny, jaki był konieczny do utrzymania i rozwoju nowożytnego państwa. Po pierwszej wojnie światowej, wg spisu ludności przeprowadzonego w 1921 roku, w Polsce było 33,1\% analfabetów wśród mieszkańców powyżej 10. roku życia. Szczególnie niski stan szkolnictwa występował na obszarze dawnego zaboru rosyjskiego, gdzie przymus szkolny nie obowiązywał. Na terenach byłej Galicji obowiązek szkolny istniał tylko formalnie, gdyż w praktyce nie był konsekwentnie realizowany. Najlepiej pod tym względem wyglądała sytuacja na obszarze byłego zaboru pruskiego, gdzie przestrzegano realizacji obowiązku 
szkolnego. W całościowej wizji oświaty w myśli politycznej stronnictw ludowych zwracają uwagę kwestie szkolnictwa powszechnego, średniego, rolniczego, wyższego, oświaty pozaszkolnej, wychowania przedszkolnego, budownictwa szkół, rozwoju wszelkich instytucji kulturalno-oświatowych. Oświata była wg nich jednym z podstawowych czynników przeobrażeń społecznych i politycznych wsi. Ludowcy zachęcali chłopów do zdobywania wiedzy zarówno ogólnej, jak i zawodowej za pośrednictwem szkół i innych form działalności oświatowej, która miała ich wprowadzić w kragg spraw publicznych i przełamać dotychczasową bierność (Rocznik statystyki Rzeczypospolitej Polskiej, 1927; Krasuski, 1993, s. 9-12; Buszko, 1984, s. 341-346; Wolańczyk, 2012, s. 116-122; Strzelecki, 2012, s. 133-149; Sytuła, 1982; Bednarza-Libera, 2007, s. 331-345).

\section{MYŚL POLITYCZNA}

Każdy z wielkich ruchów politycznych kształtujących się na przełomie XIX i XX wieku na ziemiach polskich wypracował swoją wizję ładu społeczno-politycznego. Jedno z ważniejszych miejsc zajmowała wizja Polski ludowej, odnosząca się do przyszłego, silnego państwa z wielomilionową rzeszą polskich chłopów, wypracowana przez partie ludowe. Chłopi stanowili dla polityków ruchu ludowego fundament społeczeństwa i narodu, byli inspiracją dla koncepcji i działań.

Myśl polityczna ruchu ludowego w okresie zaborów w aspekcie programowym nie była rozbudowana. Ruch dopiero się kształtował, nie miał wielu teoretyków, ideologów i koncentrował się głównie na praktycznym działaniu. Ówczesną myśl cechowała wielowątkowość, niespójność koncepcji, niejednokrotnie brak konsekwencji w formułowaniu postulatów i uogólnień. Mimo wielu słabości, została zarysowana kwestia wolnej i niepodległej Polski oraz ściśle z nią zespolona idea społecznego wyzwolenia chłopów i uczynienia ich pełnoprawnymi obywatelami państwa.

Źródła ideowych inspiracji myśli ludowej były wielorakie. Z podłoża ideowego agraryzmu wywodzono hasło solidarności chłopskiej, misji dziejowej ludu wiejskiego, roli rolnictwa w gospodarce. Głębokie inspiracje wypływały z dziejów ojczystych oraz położenia ekonomicznego chłopów, ich miejsca i roli w społeczeństwie. Koncepcje 
Inspiracje naturą chłopską myśli politycznej ruchu ludowego

te znalazły wyraz w ogłoszonych w 1886 roku przez Bolesława Wysłoucha Szkicach programowych, dokumencie o przełomowym znaczeniu dla kształtowania programu ludowego. Wysłouch głosił, że odbudowa państwa polskiego stanie się realna, gdy podejmą ją warstwy ludowe, którym przewodzą chłopi. W programie z 1903 roku, powstałego pod zaborem austriackim Polskiego Stronnictwa Ludowego, zaznaczono:

Polskie Stronnictwo Ludowe dąży do narodowego, politycznego, ekonomicznego i cywilizacyjnego podniesienia ludu i nie spocznie $\mathrm{w}$ walce, aż zniknie na ziemi naszej jak długa ona i szeroka polityczna niewola i wszelaka niesprawiedliwość społeczna (Program Polskiego Stronnictwa Ludowego..., 1903, s. 69).

Powstały w 1904 roku Polski Związek Ludowy - pierwsza partia ludowa w Królestwie Polskim, wysunął hasło „(...) walki o wolnościowe interesy Polski $(\ldots)$ ” oraz „(...) obronę interesów ekonomicznych i politycznych włościaństwa polskiego (...)” (Program Polskiego Związu Ludowego..., 1906, s. 87). Ludowcy podejmując ideę niepodległości służyli jej także poprzez praktyczną działalność: budzenie postaw patriotycznych wśród chłopów opartych na tradycji walk o niepodległość. Działacze ruchu zaraniarskiego rozwijali na wsi pod zaborem rosyjskim pracę oświatową zakładali kółka rolnicze, czytelnie, straże pożarne, domy ludowe, pobudzając chłopów do aktywnego działania. To oni upowszechnili hasło „Ziemia, władza i oświata dla ludu", które stało się przewodnia ideą ruchu ludowego. Ludowcy wskazywali wiele cech, które predestynowały chłopów do odegrania twórczej roli w społeczeństwie. Ważnym kryterium pozostawała też przewaga liczebna chłopów w stosunku do innych warstw (Wichmanowski, 2010a, s. 31-32).

Koncepcje ideologiczne stronnictw ludowych były zdeterminowane układem sił politycznych i strukturami ekonomiczno-społecznymi. Pomimo że ideologia partii ludowych ulegała ewolucji, paradygmat pozostał niezmienny, zawierał się w haśle „dobro państwa - dobrem ludu, dobro ludu - dobrem państwa” (Program Polskiego Stronnictwa Ludowego Piast..., 1926, s. 256). W programach występowały idee dotyczące ziemi jako głównego miejsca pracy, rolnictwa jako najważniejszego działu wytwórczości i chłopów jako przodującego producenta, pretendującego do pozycji lidera politycznego. W najbardziej 
krytycznych warstwach programów potępiano rolę historyczną szlachty, natomiast w warstwie konstruktywnej postulowano nadanie chłopom ziemi (Wichmanowski, 2017, s. 38).

Myśl polityczna ludowców nosiła cechy rozrachunku z okresem feudalizmu, pańszczyzny, poddaństwa. Liderzy partii zmieniali świadomość chłopów i zakodowaną w niej negatywną ocenę przeszłości (Wichmanowski, 2017, s. 42). Obserwując zainteresowania stronnictw ludowych problematyką gospodarczą i oświatową na wsi, chłopi przekonali się, że dla partii ludowych ważne były uczucia i sprawy chłopów i nimi kierowano się przy tworzeniu programów. Wiele elementów myśli politycznej stronnictw ludowych opierało się na związku dwu fundamentalnych idei - odrodzenia, a następnie umacniania niepodległego państwa i należnego w nim prestiżu społecznego chłopów. Najbardziej pełnym i dojrzałym przekazem samodzielnej chłopskiej myśli politycznej były programy stronnictw ludowych, w których zawarto postulaty zmian gwarantujących chłopom wyjście z upośledzenia społecznego i politycznego.

Myśl polityczna ruchu ludowego, niejednokrotnie inspirowana naturą chłopską, powstawała po analizie faktów w kategoriach zjawisk dużo wcześniejszych. Ważne były inspiracje wartościami konserwatywnymi zakorzenionymi w naturze chłopskiej: tradycją wiara, religia, rodzina, rolą wspólnot lokalnych, także nauką społeczną Kościoła katolickiego, wyrażoną w encyklikach Leona XIII Rerum novarum (1891) i Piusa XI Quadragesimo Anno (1931) (Leon XIII, 1891, s. 11-35; Pius XI, 1931, s. 37-75). Twórcy myśli politycznej znając chłopską naturę, podejmowali wysiłek, by poprzez swoistą artykulację, nawiązującą do postaw, poglądów, uczuć i przekonań chłopskich, dotrzeć do odbiorcy. Jeżeli nawet nie udało im się trafić do wszystkich chłopów, to zapewne chociaż do jakiejś ich części. Analizując naturę polskiego chłopa, liderzy ruchu ludowego położyli nacisk na jego specyficzne cechy i zastanawiającą trwałość zbudowanego z nich wzoru osobowego (Bukraba-Rylska, 2008, s. 89; Gmitruk, 2014, s. 11-38).

\section{UOBYWATELNIENIE CHŁOPÓW}

Począwszy od drugiej połowy XIX wieku prawie wszystkie środowiska polityczne „umocnienie sił narodowych” wiązały z włączeniem 
chłopów w życie narodowe. Jednak w swej masie chłopi, „bali się Polski wierząc, że z jej powrotem przyjdzie (...) pańszczyzna i szlachecka niewola" (Witos, 1978, s. 84-85). Podstawowym obowiązkiem, jaki stanął przed politykami stronnictw ludowych, było uświadomienie chłopom, że odrodzenie niepodległej Polski oznaczać będzie uzyskanie przez nich pełni praw obywatelskich. W programach partii ludowych został podkreślony związek niepodległości państwa polskiego z ideą sprawiedliwości społecznej, a także emancypacji politycznej, gospodarczej i oświatowej chłopów. W wydanej przez PSL „Wyzwolenie” w październiku 1918 roku odezwie Bracia chtopi oświadczono, że „Polska ma być Zjednoczona i Niepodległa, Polska ma być Ludową Rzeczpospolitą (...) Sejm (...) uchwali prawa ludowe, szerokie reformy społeczne i Zaspokoi Głód Ziemi" (Odezwa PSL w Królestwie..., 1918, s. 480-481). Jako antyteza Polski szlacheckiej, w programach występowała idea Polski ludowej. Przy ówczesnym stanie świadomości chłopów, których schematy myślowe kształtował odruch antypańszczyźniany, postulaty określonej formy rządów były mniej zrozumiałe od konkretnego obrazu - Polski ludowej (Sielezin, 2013, s. 11-40; Wichmanowski, 2010a, s. 150-151).

Wybuch pierwszej wojny światowej oznaczał dla polskich ugrupowań politycznych pojawienie się nowych warunków dla podjęcia i rozwiązywania sprawy polskiej, w tym chłopskiej. Wojna stanowiła przełomowy etap w kształtowaniu postawy narodowej chłopów. Ludowcy przyczynili się do zaangażowania ich do czynu narodowo-wyzwoleńczego. Jednocześnie myśl ludowa wyrażała dążenie, że ta wolna Polska będzie ludowa, spełni nadzieje na lepsze, nowe życie. Od XIX wieku Polacy służyli w armiach zaborczych. Większość szeregowych żołnierzy stanowili chłopi. W pierwszej wojnie światowej w mundurach zaborców walczyło $2 \mathrm{~m} \ln 450$ tys. Polaków. W austriackich służyło 900 tys., w niemieckich -800 tys., w rosyjskich -750 tys. Zginęło około 400 tys. Polaków walczących przeciwko sobie. Pamięć zbiorową walczących o niepodległość Polski ukształtowała dopiero obrona Lwowa (1918-1919), powstanie wielkopolskie (19181919), trzy powstania śląskie $(1919,1920,1921)$ i zwycięska wojna polsko-radziecka (1919-1920). Wydarzenia te - a nie lata pierwszej wojny światowej, kiedy Polacy walczyli w obcych armiach - ukonstytuowały narodowy mit walki za ojczyznę (Wichmanowski, 2017, s. 335). 
Po wojnie chłopi nie mogli „pomieścić się” w dotychczasowym układzie społecznym i gospodarczym. Liderzy ruchu ludowego podjęli inicjatywę zaprowadzenia nowego ładu. Sama idea nie wystarczyła, więc musieli ją uzupełnić konkretnym programem przebudowy porządku społecznego. Odzyskanie niepodległości wywołało ożywienie polityczne chłopów i stworzyło sprzyjające warunki dla dalszego rozwoju ich świadomości narodowej, społecznej i politycznej. Chłopi w swej masie zachowali polski język, wiarę katolicką i ziemię. To bardzo ważne elementy wspólnoto- i narodotwórcze, niezwykle kształtujące tożsamość i kulturę wspólnoty. Należy podkreślić nieporównywalny stan świadomości i aktywności politycznej chłopów jako zbiorowości w końcu XIX wieku i u progu niepodległości. Korespondent gazety „Piast” napisał: „Panowie wiedzą, że władanie nad chłopem z rąk im się wymyka" (Krężel, 1919, s. 7; Sytuła, 1982).

Politycy ludowi uważali, że rola chłopów nie była adekwatna do miejsca, jakie zajmowali w harmonijnie działającym społeczeństwie. Byli przeciwni sytuacji, w której ludu wiejskiego w swej większości nie uważano za pełnoprawnych członków narodu polskiego. $\mathrm{Z}$ niepodległym państwem i ustrojem republikańskim stronnictwa ludowe wiązały realizację ludowładztwa, w którym podmiotem władzy byłby lud. Konsekwencją refleksji liderów partii chłopskich było stwierdzenie, że w niepodległym państwie nie można odsunąć $3 / 4$ narodu od władzy. Tym samym uznali za konieczny taki program odbudowy państwa, który uwzględniłby podmiotową rolę chłopów w sprawowaniu władzy. Równocześnie podkreślali, że wprawdzie: „chłop jest (...) najliczniejszą częścią ale tylko częścią narodu i państwa", dlatego nie zapomnieli wskazać mu jego obowiązków względem całości. Tłumaczono chłopom, że do objęcia władzy należy się odpowiednio przygotować. „Ty, bracie-chłopie najpierw umysł musisz zreformować, musisz zrozumieć czem jesteś, musisz połączyć się i poznać chłopską naszą siłę" (Ślusarczyk, 1918, s. 9). Ważnym w kwestii władzy dla chłopów był artykuł drugi Konstytucji marcowej z 1921 roku, w którym zapewniono „Władza zwierzchnia w Rzeczypospolitej Polskiej należy do Narodu" (Konstytucja Rzeczypospolitej Polskiej..., 1921, s. 70). W połowie lat dwudziestych XX wieku ludowcy przyjęli zasadę, że ",jak lud jest trzonem narodu", tak rdzeniem ludu byli chłopi, z których rozrósł 
Inspiracje naturą chłopską myśli politycznej ruchu ludowego

się naród polski. Witos wspominał, że chłopom przy każdej sposobności powtarzał:

Polska jest waszą własnością (...). Starajcie się, aby państwo było dobrze rządzone i mocne, bo wtenczas tylko można na nim polegać. Macie równe prawa ze wszystkimi i ogromną większość w narodzie. Możecie urządzić państwo jak zechcecie, jeżeli będziecie do tego zdolni (Zakrzewski, 1968, s. 574).

W chłopach rozbudzono świadomość ich siły w państwie i społeczeństwie. Większość zdobyła poczucie podmiotowości i umiejętność realizacji własnych planów. Spotkało ich jednak rozczarowanie. Nadal odczuwali pogardę „wszelkich panów”, którzy dawali poznać, że nie traktują ich jak równych sobie. Nieprzyjazny stosunek do chłopów zaczął się nasilać po upadku ostatniego rządu Wincentego Witosa. Ludowcy twierdzili, że w osobie Witosa „sponiewierano cały lud polski”. Apelowali do chłopów, by w niepodległej Polsce wyzbyli się "pańszczyźnianych odruchów”, a w tym miał im pomóc ruch ludowy.

\section{ZAKOŃCZENIE}

W swych poglądach, twórcy myśli politycznej ruchu ludowego nasyconej zarówno utopią jak i realizmem kładli nacisk na analizę rzeczywistości, a w niej stopniowa, pozytywną zmianę ukształtowanej przez wieki natury chłopskiej. Myśl polityczną tworzyły elity stronnictw: liderzy, politycy, publicyści, a także liczni chłopi, z których „naturą" należało się liczyć. W ideologii ruchu ludowego znalazły wyraz ich dążenia do współdecydowania o charakterze rozwoju gospodarczego oraz politycznego państwa, a także uzasadnienia wiodącej roli w życiu społeczeństwa i państwa. Powstała swego rodzaju piramida wartości, która zawierała cztery poziomy: 1) ziemia, człowiek, praca; 2) rodzina, gmina, samorząd; 3) naród, ojczyzna, państwo; 4) ludzkość. W myśli politycznej ruchu ludowego mocno akcentowano także sprawy odrodzenia moralnego chłopów, duchowego i gospodarczego oraz pracy samokształceniowej. Przyjmując te wartości i biorąc pod uwagę oczekiwania chłopów, ideolodzy ruchu ludowego wypracowali własny model organizacji państwa i społeczeństwa - Polskę ludową (Sielezin, 2018; Wichmanowski, 2017, s. 36-37). 
Ideologia ruchu ludowego wskazywała, że wszelkie działanie polityczne ma uzasadnienie wówczas, gdy jego wyniki i efekty będą służyły człowiekowi. Stąd też dążono do przebudowy psychiki chłopa (uszlachetnienia go). Od narodzin ruchu ludowego jego działania zmierzały: po pierwsze - do transformacji zamkniętej przestrzennie społeczności wiejskiej (lokalnej) do społeczności narodowo-państwowej (ponadlokalnej) i po drugie - do związania z nią transformacji pozycji chłopa człowieka przytwierdzonego do ziemi, raz na zawsze określonego, skończonego, pozbawionego historii, do pozycji człowieka wolnego, dysponującego przestrzenią nieograniczoną i w konsekwencji do pełnoprawnego obywatela. Proces ten stymulował postęp cywilizacyjny.

Ideologia ruchu ludowego głęboko tkwiła w wartościach narodowych i patriotycznych, co w polskich warunkach wyrażało hasło „Żywią i Bronią". W myśl tej ideologii jednostka (chłop) powinna mieć zagwarantowane swobody obywatelskie i równość wobec prawa. Równocześnie mocno podkreślano świadomość odpowiedzialności obywatela wobec społeczeństwa, poszanowania praw współobywateli, postępowania zgodnie z prawem i wypełniania obowiązków nałożonych na niego przez społeczeństwo (Program Polskiego Stronnictwa Ludowego „Wyzwolenie”..., 1925, s. 224-225; Program Polskiego Stronnictwa Ludowego "Piast"..., 1926, s. 255-256; Program Stronnictwa Ludowego..., 1931, s. 300).

W miarę zaniku izolacji społecznej wsi i wchodzenia jej w orbitę systemu kapitalistycznego i społeczności narodowo-państwowej zmieniała się tradycyjna struktura społeczności wiejskiej, a szczególnie buntowniczego czy rewolucyjnego młodego pokolenia. Powodowało to zarazem zmiany w społecznej roli chłopów w życiu zbiorowym, prowadząc do coraz bardziej liczącego się uczestnictwa w życiu narodu. Ludowcy brali udział w inicjowaniu i przyspieszaniu procesów narodotwórczych na wsi poprzez walkę o stworzenie ekonomicznych podstaw egzystencji rodziny wiejskiej, rozbudowę szkolnictwa i oświaty na wsi, o pełnię praw społecznych i politycznych (Bilewicz, Gładkiewicz, Walasek, 2002). W gospodarce uznano rolnictwo za podstawę nie tylko ze względu na efektywność produkcyjną i „miłość chłopa do ziemi”, ale też za stwarzanie najkorzystniejszych warunków dla wychowania zdrowych moralnie, światłych i prawdziwie ideowych obywateli. 
Inspiracje naturą chłopską myśli politycznej ruchu ludowego

Pracując nad wydźwignięciem chłopów z nizin społecznych, nad wprowadzeniem ich do społeczności narodowej, równocześnie dbano o zachowanie indywidualności jednostki. Wielu działaczy chłopskich dzięki ruchowi ludowemu przeszło klasyczną drogę od społecznikostwa do pracy politycznej i państwowej.

Myśl ludowa ukształtowała nowy wzór osobowy chłopa. Łączono postawę chłopa-obywatela, chłopa-żołnierza z wzorem obywatela-chrześcijanina i gospodarza ziemi ojczystej. Przeciwstawiano się ekstremalnym i radykalnym wystąpieniom w kwestiach społecznych, nawoływano do legalizmu działań i poszanowania prawa.

Partie i organizacje chłopskie wyrastały na rodzimej glebie. Były zakorzenione w narodowej oraz ludowej tradycji. Przy formułowaniu myśli politycznej brano pod uwagę wady i zalety chłopów, ich marzenia, oczekiwania i obawy, a także sytuację społeczno-polityczną. Mocno akcentowano sprawy odrodzenia moralnego, duchowego i cywilizacyjnego chłopów.

\section{Bibliografia}

Banach, A., K. (1997). Awans młodzieży chłopskiej na przykładzie studentów Uniwersytetu Jagiellońskiego w latach 1867-1918. W: C. Kłak (red.). Chtopi-naród - kultura, t. 3: Oblicze duchowe (83-94). Rzeszów: Wydawnictwo Wyższej Szkoły Pedagogicznej.

Bednarzak-Libera, M. (2007). Działalność towarzystw oświatowych wśród chłopów w Europie Środkowej do 1914 roku. W: J.R. Szaflik, J. Gmitruk, A. Koseski, K. Łukawski, R. Turkowski (red.). Dzieje partii i stronnictw chłopskich w Europie, t. 1: Narodziny i rozwój (331-346). Pułtusk - Warszawa: Akademia Humanistyczna im. Aleksandra Gieysztora, Ludowe Towarzystwo Naukowo-Kulturalne, Muzeum Historii Polskiego Ruchu Ludowego.

Bilewicz, A., Gładkiewicz, R., Walasek S. (2002). Edukacja - państwo naród w Europie Środkowej i Wschodniej w XIX i XX wieku. Wrocław: Uniwersytet Wrocławski - Instytut Pedagogiki, Centrum Badań Śląskoznawczych i Bohemistycznych.

Bojko, J. (1904). Dwie dusze. Kraków: Nakładem „Przyjaciela Ludu”.

Bukraba-Rylska, I. (2008). Socjologia wsi polskiej. Warszawa: Wydawnictwo Naukowe PWN SA.

Chałasiński, J. (1984). Młode pokolenie chłopów: procesy i zagadnienia ksztattowania się warstwy chtopskiej w Polsce, t. 1-4. Warszawa: Ludowa Spółdzielnia Wydawnicza. 
Czarnota, A. (1988). Problemy syntezy polskiej myśli politycznej - rozważania wstępne. W: W. Wrzesiński (red.). Polska myśl polityczna XIX i XX wieku, t. 7: Państwo w polskiej myśli politycznej (265-279). Wrocław - Warszawa - Kraków - Gdańsk - Łódź: Wydawnictwo Ossolineum.

Garlicki, A. (1981). Wstęp. W: A. Garlicki (red.). Przewroty i zamachy stanu: Europa 1918-1939 (5-9). Warszawa: Spółdzielnia Wydawnicza Czytelnik.

Jachymek, J. (1983). Myśl polityczna PSL Wyzwolenie 1918-1931. Lublin: Wydawnictwo Lubelskie.

Jachymek, J. (1993). Neoagraryzm i trzecia droga. Przebudowa i walka o nowa Polskę, Lublin: Wydawnictwo Czas.

Jachymek, J. (2001). Ruch ludowy. W: J. Jachymek, W. Paruch (red.). Więcej niż niepodległość: Polska myśl polityczna 1918-1939 (221-257). Lublin: Wydawnictwo Uniwersytetu Marii Curie-Skłodowskiej.

Jachymek, J., Paruch, W. (2001). Wstęp. W: J. Jachymek, W. Paruch (red.). Więcej niż niepodległość: Polska myśl polityczna 1918-1939 (9-14). Lublin: Wydawnictwo Uniwersytetu Marii Curie-Skłodowskiej.

Jajecznik, K. (2006). Myśl polityczna - próba standaryzacji badań. Rocznik Nauk Politycznych, 9, 255-270.

Konstytucja Rzeczypospolitej Polskiej. (1921, 17 marca). W: J.R. Szaflik (oprac. 1998). Źródła do dziejów Polski w XIX i XX wieku, t. 3: Lata 1918-1939 Polska niepodległa. Wybór tekstów źródłowych (69-85). Pułtusk: Wydawnictwo Wyższej Szkoły Humanistycznej w Pułtusku.

Krężel, A. (1919, 9 listopada). Ostatnim zwolennikom szlacheckiego jarzma. Piast, 45, 7.

Król, M. (1998). Historia myśli politycznej: Od Machiavellego po czasy wspótczesne. Gdańsk: Wydawnictwo Arche.

Leon XIII. (1891). Rerum novarum. Encyklika o kwestii robotniczej. W: J. Skwara (oprac. 1984). Nauczanie społeczne Kościoła. Dokumenty (11-35). Warszawa: Ośrodek Dokumentacji i Studiów Społecznych.

Łuczak, A. (1982). Społeczeństwo i państwo w myśli politycznej ruchu ludowego. Warszawa: Ludowa Spółdzielnia Wydawnicza.

Maj, E., Wójcik, A. (2008). Wstęp. W: E. Maj, A. Wójcik (red.). Myśl polityczna w Polsce po 1989 roku. Wybrane nurty ideowe (7-11). Lublin: Wydawnictwo Uniwersytetu Marii Curie-Skłodowskiej.

Odezwa PSL w Królestwie Polskim Pt. "Bracia Chłopi” o reformach społeczno-politycznych i roli chłopów w budowie niepodległego państwa polskiego. (1918, październik). W: K. Dunin-Wąsowicz i in. (oprac. 1966). Materiały źródłowe do historii polskiego ruchu ludowego, t. 1: 1864-1918 (480-481). Warszawa: Ludowa Spółdzielnia Wydawnicza. 
Olszewski, E. (2015). Wybrane problemy myśli politycznej: idea, ideologia, doktryna polityczna. W: E. Maj, E. Kirwiel, E. Podgajna (red.). Myśl polityczna w społeczeństwie informacyjnym (153-174). Lublin: Wydawnictwo Uniwersytetu Marii Curie-Skłodowskiej.

Paruch, W. (1997). Od konsolidacji państwowej do konsolidacji narodowej: Mniejszości narodowe w myśli politycznej obozu piłsudczykowskiego (19261939). Lublin: Wydawnictwo Uniwersytetu Marii Curie-Skłodowskiej. Paruch, W. (1999). Myśl polityczna - refleksje metodologiczne o pojęciu. W: Z.J. Pietraś, A. Wójcik, W. Paruch (red.). Państwo - ludowcy - myśl polityczna (27-39). Lublin: Annales Universitatis Mariae Curie-Skłodowska. Sectio K: Politologia.

Paruch, W. (2004). Między wyobrażeniami a działaniami. Wybrane aspekty przedmiotowe badań politologicznych nad myślą polityczna, Polityka i Społeczeństwo, 1, 9-38.

Paruch, W. (2005). Myśl polityczna obozu piłsudczykowskiego 1926-1939. Lublin: Wydawnictwo Uniwersytetu Marii Curie-Skłodowskiej.

Paruch, W. (2009). Kategorie ekonomiczne a zakres pojęcia „myśl polityczna" - refleksje metodologiczne. W: E. Maj, S. Michałowski, A. Wójcik (red.). Idee - Państwo - Ludowcy. Ksiega jubileuszowa z okazji 70. rocznicy urodzin Profesora Jana Jachymka (37-46). Lublin: Wydawnictwo Uniwersytetu Marii Curie-Skłodowskiej.

Paruch, W. (2015). Konsekwencje definiowania myśli politycznej dla kwestionariusza badań politologicznych. Humanities and Social Science, 22(1), 157-174.

Pius XI. (1931). Qadragesimo anno. Encyklika o odnowieniu ustroju społecznego i o udoskonaleniu go według normy prawa Ewangelii. W: J. Skwara (oprac. 1984). Nauczanie społeczne Kościoła. Dokumenty (37-75). Warszawa: Ośrodek Dokumentacji i Studiów Społecznych.

Program Polskiego Stronnictwa Ludowego Piast. (1926, 29 listopada). W: S. Lato, W. Stankiewicz (1969). Programy stronnictw ludowych: Zbiór dokumentów (255-281). Warszawa: Państwowe Wydawnictwo Naukowe.

Program Polskiego Stronnictwa Ludowego Wyzwolenie. (1925, 16 marca). W: S. Lato, W. Stankiewicz (1969). Programy stronnictw ludowych: Zbiór dokumentów (229-244). Warszawa: Państwowe Wydawnictwo Naukowe.

Program Polskiego Stronnictwa Ludowego. (1903, 27 lutego). W: S. Lato, W. Stankiewicz (1969). Programy stronnictw ludowych: Zbiór dokumentów (69-83). Warszawa: Państwowe Wydawnictwo Naukowe.

Program Polskiego Związku Ludowego. (1906, 29 czerwca). W: S. Lato, W. Stankiewicz (1969). Programy stronnictw ludowych: Zbiór dokumentów (87-90). Warszawa: Państwowe Wydawnictwo Naukowe. 
Program Stronnictwa Ludowego. (1931, 15 marca). W: S. Lato, W. Stankiewicz (1969). Programy stronnictw ludowych: Zbiór dokumentów (299-311). Warszawa: Państwowe Wydawnictwo Naukowe.

Rocznik statystyki Rzeczypospolitej Polskiej. (1927), R. 5, Warszawa: Główny Urząd Statystyczny.

Samulak, T. (1997). Historia i współczesność kwestii chłopskiej w Polsce W: W. Bonusiak (red.). Chłopi-naród - kultura, t. 5: Chłopi a państwo (11-22). Rzeszów: Wydawnictwo Wyższej Szkoły Pedagogicznej.

Scrutona, R. (2002). Słownik myśli politycznej, przełożył T. Bieroń. Poznań: Wydawnictwo Zysk i S-ka.

Sielezin, J.R. (2013). Wizja państwa w myśli politycznej partii chłopskich w II Rzeczypospolitej. Rocznik Historyczny Muzeum Historii Polskiego Ruchu Ludowego, 29, 11-40.

Sielezin, J.R. (2018). W kręgu myśli politycznej polskiego ruchu ludowego. Artykuty i szkice. Warszawa: Wydawnictwo Muzeum Historii Polskiego Ruchu Ludowego.

Skarzyński, R. (1990). Intelektualiści a ideologia. Myśl polityczna jako przedmiot badań politologa. Studia Nauk Politycznych, 4-6, 9-27.

Skarzyński, R. (1992). Historia myśli politycznej w ujęciu politologicznym: Zarys koncepcji. Studia Polityczne, 1, 107-119.

Słomka, J. (1983). Pamiętniki włościanina. Od pańszczyzny do dni dzisiejszych. Warszawa: Ludowa Spółdzielnia Wydawnicza.

Strzelecki, M. (2012). Świadomość społeczno-polityczna chłopów i jej determinanty w refleksji działaczy ruchu ludowego w latach 1918-1939. W: J. Gmitruk, A. Indraszczyk (red.). Wieś i ruch ludowy w Polsce i Europie, t: 1: W kręgu historii i tradycji (133-149). Warszawa: Muzeum Historii Polskiego Ruchu Ludowego, Wydział Nauk Humanistycznych Szkoły Głównej Gospodarstwa Wiejskiego w Warszawie, Ludowe Towarzystwo Naukowo-Kulturalne.

Sytuła, J. (1982), Miejsce kształcenia dorostych w systemie oświatowym II Rzeczypospolitej. Wrocław - Warszawa - Kraków - Gdańsk - Łódź: Zakład Narodowy im. Ossolińskich.

Szmyd, J. (1996). Tożsamość chłopska - charakter i ethos narodowy polskość. W: A. Meissner (red.). Chłopi - naród - kultura, t. 4: Kultura i oświata wsi (11-26). Rzeszów: Wydawnictwo Wyższej Szkoły Pedagogicznej.

Ślusarczyk, A. (1918, 10 listopada). Gdy Polska powstaje!... Piast, 45, s. 9. Wapiński, R. (1987). Badania nad dziejami polskiej myśli politycznej schyłku XIX i XX wieku. Przeglad Humanistyczny, 9 (264), 51-70.

Wapiński, R. (1990). Badania nad dziejami polskiej myśli politycznej schyłku XIX i XX wieku W: J. Maternicki (red.). Historia najnowsza 
Inspiracje naturą chłopską myśli politycznej ruchu ludowego

jako przedmiot badań i nauczania (169-178). Warszawa: Państwowe Wydawnictwo Naukowe.

Wichmanowski, M. (2010a). Działalność i myśl polityczna Aleksandra Bogustawskiego (1887-1963) polityka ruchu ludowego. Lublin: Wydawnictwo Uniwersytetu Marii Curie-Skłodowskiej.

Wichmanowski, M. (2010b). Źródła i rozwój nacjonalizmu chłopskiego. Wybrane problemy. W: E. Maj, M. Mikołajczyk, M. Śliwa (red.). Idee w procesie kształtowania wspótczesnej rzeczywistości polskiej. Nacjonalizm (159-180). Kraków: Wydawnictwo Naukowe Uniwersytetu Pedagogicznego.

Wichmanowski, M. (2017). Myśl polityczna Polskiego Stronnictwa Ludowego "Piast" 1913/14-1931. Lublin: Wydawnictwo Uniwersytetu Marii Curie-Skłodowskiej.

Wichmanowski, M. (2019). Demokracja w myśli politycznej ludowców w okresie międzywojennym: Wybrane problemy. W: E. Kirwiel, E. Maj, E. Podgajna, M. Wichmanowski (red.). Myśl polityczna - demokracja - wolność. Księga Jubileuszowa dedykowana Profesorowi Janowi Jachymkowi z okazji 80. rocznicy urodzin (311-328). Lublin: Wydawnictwo Uniwersytetu Marii Curie-Skłodowskiej.

Witos, W. (1978). Moje wspomnienia, A. Czubiński i in. (oprac.). Warszawa: Ludowa Spółdzielnia Wydawnicza.

Witos, W. (1998). Dzieła wybrane, t. 1: Moje wspomnienia, cz. 1. E. Karczewski, J.R. Szaflik (oprac.). Warszawa: Ludowa Spółdzielnia Wydawnicza.

Wolańczyk, M. (2012). Rozwój świadomości narodowej galicyjskich chłopów na przełomie XIX i XX wieku na podstawie pamiętników i wspomnień. W: J. Gmitruk, A. Indraszczyk (red.). Wieś i ruch ludowy w Polsce i Europie, t: 1: W kręgu historii i tradycji (115-122). Warszawa: Muzeum Historii Polskiego Ruchu Ludowego, Wydział Nauk Humanistycznych Szkoły Głównej Gospodarstwa Wiejskiego w Warszawie, Ludowe Towarzystwo Naukowo-Kulturalne.

Wójcik, A. (1992). Myśl polityczna Stanisława Augusta Thugutta 1873-1941. Lublin: Wydawnictwo Uniwersytetu Marii Curie-Skłodowskiej.

Zakrzewski, A. (1968). Wincenty Witos - chłopski mąż stanu w latach 1918-1926. Kwartalnik Historyczny, 3, 574.

Zakrzewski, A. (1988). Państwo w programach stronnictw ludowych. W: W. Wrzesiński (red.). Polska myśl polityczna XIX i XX wieku, t. 7: Państwo w polskiej myśli politycznej (121-135). Wrocław - Warszawa Kraków - Gdańsk - Łódź: Wydawnictwo Ossolineum.

Zieliński, H. (1975). O potrzebie i trudnościach badania dziejów polskiej myśli politycznej. W: H. Zieliński (red.). Polska myśl polityczna XIX 
i XX wieku, t. 1: Polska i jej sasiedzi (7-26). Wrocław - Warszawa - Kraków - Gdańsk: Wydawnictwo Ossolineum.

\section{Copyright and License}

This article is published under the terms of the Creative Commons Attribution - NoDerivs (CC BY- ND 4.0) License http://creativecommons.org/licenses/by-nd/4.0/ 